\title{
KARATERISTIK RESILIENSI PADA PASIEN HIV DI KABUPATEN KARO
}

\author{
Friska Ginting \\ Staff Pengajar STIKes Santa Elisabeth Medan \\ E-mail : friskaginting20@ gmail.com
}

\begin{abstract}
Background: Human Immuno deficiency Virus (HIV) is a disease that requires an bio-psychosocio-spiritual approach. The life of an HIV sufferer is very dependent on the surrounding environment. The most dominant influence on HIV sufferers is healthy behavioral, psychological and physical functions of others' ability to be able to accept the attitudes and behavior of others to support the social life of HIV sufferers. Viewed from the sex, women are more vulnerable and more sensitive in accepting the conditions they suffer. HIV has become a pandemic that causes world anxiety. Individuals who suffer from HIV positive with high resilience will have more enthusiasm for life.

Method: This type of research is an analytic survey research using descriptive design that aims to identify resilience in HIV sufferers. The population in this study were 90 people with HIV diagnoses, both men and women in Karo District, while the sample for this study was based on sample criteria.

Results: The results obtained from the frequency distribution table showed that the majority of HIV sufferers' work history were 18 people (58.0\%), 11 drivers (35.5) and 2 (6) housewives (IRT) 5\%). Based on the sex of the female as many as 20 people (64.5\%) and the male sex as many as 11 people (35,\%), from the age of the patients found 25-35 years as many as 25 people (80.6\%), aged 36-45 years as many as 5 people (16.1\%) and $\geq 46$ years old as many as 1 person (3.3\%). And the highest level of education is at the high school level of 25 people (54.3\%).

Conclusion: Based on the results of the study, it is recommended that HIV sufferers consult more often about physical and psychological conditions at the nearest health center.
\end{abstract}

Keywords: Characteristics, HIV

\begin{abstract}
ABSTRAK
Latar Belakang : Human Immuno deficiency Virus (HIV) merupakan penyakit yang memerlukan pendekatan dari segi bio-psiko-sosio-spiritual. Kehidupan penderita HIV sangat tergantung dengan lingkungan sekitarnya. Pengaruh yang sangat dominan pada penderita HIV yaitu perilaku, fungsi psikologis dan fisik yang sehat kemampuan orang lain untuk dapat menerima dengan baik sikap dan sifat orang lain untuk mendukung kehidupan social penderita HIV itu dinilai dari pribadi diri sendiri. Dilihat dari jenis kelamin, wanita lebih rentan dan lebih sensitive dalam menerima kondisi keadaan yang dideritanya. Penyakit HIV telah menjadi pandemi yang menimbulkan kecemasan dunia. Individu yang menderita HIV positif dengan resiliensi yang tinggi akan lebih mempunyai semangat hidup.
\end{abstract}


Metode : Jenis penelitian ini adalah penelitian survei analitik dengan menggunakan desain deskriptif yang bertujuan untuk mengidentifikasi resiliensi pada penderita HIV. Populasi dalam penelitian ini adalah 90 orang dengan diagnosa HIV, baik laki-laki maupun perempuan di Kabupaten Karo, sedangkan sampel untuk penelitian ini berdasarkan kriteria sampel.

Hasil : Hasil penelitian yang diperoleh dari tabel distribusi frekuensi menunjukkan bahwa riwayat pekerjaan penderita HIV mayoritas adalahwiraswasta sebanyak 18 orang (58,0\%), supir 11 orang sebanyak $(35,5)$ dan ibu rumah tangga (IRT) sebanyak 2 orang $(6,5 \%)$. Berdasarkan jenis kelamin perempuan sebanyak 20 orang $(64,5 \%)$ dan jenis kelamin laki-laki sebanyak 11 orang $(35, \%)$,dari usia pasien didapati25-35tahun sebanyak 25orang(80,6\%), usia 36-45 tahun sebanyak 5 orang $(16,1 \%)$ dan usia $\geq 46$ tahun sebanyak 1 orang $(3,3 \%)$. Dan tingkat pendidikan terbanyak pada tingkat SMA 25 orang $(54,3 \%)$.

Kesimpulang : Berdasarkan hasil penelitian, disarankan bagi penderita HIV agar lebih sering berkonsultasi mengenai keadaan fisik maupun psikologis di Puskesmas terdekat.

\section{Kata Kunci : Karateristik, HIV}

\section{PENDAHULUAN}

Human Immunodeficiency Virus atau yang sering dikenal dengan HIV merupakan penyakit yang memerlukan pendekatan dari segi bio-psiko-sosio-spiritual, dan bukan dari segi klinis semata. Aspek kehidupan yang dapat dipengaruhi oleh HIV adalah Pekerjaan, hubungan sosial, danlingkungan.Klien HIV sering mengalami kepanikan ketakutan yang berlebihan, kecemasan, serta ketidakpastian, keputusasaan, dan stigma. HIV telah menjadi pandemi yang menimbulkan kecemasan dunia (Djoerban, 2012).Melalui Organisasi Kesehatan Dunia (WHO)tahun 2013, diungkapkan angka yang tercatatpada orang yang hidup dengan HIV berjumlah 35 juta jiwa dan pada orang yang baru terinfeksi HIV berjumlah 2,1 juta jiwa.

Di Sumatera Utara jumlah penderita batu terinveksi HIV pada tahun Maret 2016 sebanyak 209 orang dengan jumlah kumulatif sampai dengan Maret 2016 sebanyak 11295. Khususnya didaerah kabupaten karo penderita HIV meningkat dari tahun ke tahun yang diakibatkan oleh narkoba, menurut data dinas kesehatan kabupaten karo tahun 2016 penderita HIVsebanyak549 orang dengan rincian laki-laki 337 orang dan perempuan 212orang.Resiliensi (resilience)

merupakan kemampuan seseorang untuk menghadapi, mengatasi, mempelajari, atau berubah melalui kesulitan-kesulitan yang tak terhindarkan (Grotberg,2003).

Beberapa penelitian telah menyimpulkan bahwa resiliensi mempunyai peran yang sangat penting dalam menentukan kemampuan individu untuk mampu bertahan dalam mengatasi masalah dan mempertahankan diri dalam situasi yang menekan, mampu beradaptasi dan belajar dalam situasi tersebut serta mencapai suatu kehidupan yang lebihbaik.Salah satu faktor yang mendukung resiliensi diantaranya adalah fungsi intelektual sehat sehingga seseorang mampu untuk menghadapi, mengatasi, mempelajari, atau berubah melalui kesulitan- kesulitan yang tak terhindarkan (Cahill \& valladez,2013).

Di dalam resiliensi internal protective factors yang juga mempengaruhi adalah self esteem. Self esteem mengacu pada suatu gambaran 
menyeluruh dari individu terkait harga diri. Memilikiselfesteem yang baik dapat membantu individu dalam menghadapi kesengsaraan (Owens, 2006).

Hasil survey awal yang dilakukan oleh peneliti dengan melakukan wawancara mendalam terhadap beberapa orang penderita HIV yang berkunjung ke Puskesmas Kabupaten Karo menyatakan bahwa hidup mereka tidak mempunyai arti lagi dan tidak ada kebanggan pada diri merekalagi.

Pada survei awal peneliti membagikan resiliensi $65 \%$ dari 15 orang penderita mengalami resiliensi rendah. Sebanyak 8 dari 15 pasien HIV yang dilakukan wawancara oleh peneliti mengatakan begitu sulitnya seorang pasien mengerti dan memahami perasaan orang lain dalam menghadapi masalah sulit karena dia juga sedang mengalami hal yang berat, sebanyak 10 dari 15 orang pasien HIV yang dilakukan wawancara mengalami penurunan kondisi fisik sangat sulit menerima bantuan dari orang sekitar ada perasaan tidak percaya diri. Tidak ada semangat menjalani hidup setelah divonis terkena HIV, putus asa dan tidak memiliki harapan tetap hidup.

Dari latar belakang diatas, peneliti tertarik melakukan penelitian untuk mengidentifikasi karateristik penderita HIV.

\section{METODE PENELITIAN}

Jenis penelitian ini menggunakan desain deskripif.Penelitian dilakukan di Puskesmas Kabanjahe Kabupaten Karo pada bulan Mei 2018.

Populasi dalam penelitian ini adalah 90 orang dengan diagnosa HIV baik lakilaki maupun dan di kabupaten Karo Teknik pengambilan sampel dalam penelitian ini adalah dengan menggunakan teknik non probabilitysampling yaitu teknik sampling yang tidak dilakukan secara acak. Sampel dalam penelitian ini adalah seluruh responden penderita HIV di Puskesmas Padang Bulan dengan kriteria pengambilan sampel (inklusi) yaitu 1). Penderita HIV yang telah di diangnosa oleh Dokter. 2). Dapat berkomunikasi dengan baik.

\section{Variable penelitian Pekerjaan}

Hasil dalam penelitian ini riwayat pekerjaan pasienHIV adalahwiraswasta sebanyak 18 orang $(58,0 \%)$, supir 11 orang sebanyak $(35,5)$ dan ibu rumah tangga (IRT) sebanyak 2 orang (6,5\%). Pekerjaan merupakan sesuatu hal yang dilakukan untuk mendapat imbalan atau balas jasa. Setiap beban kerja dapat mengakibatkan timbulnya stress kerja. Stress akan mempengaruhi kesehatan, psikologi, dan interaksiinterpersonal.

\section{Jenis Kelamin}

Hasil dalam penelitian ini memperoleh bahwa jenis kelamin perempuan sebanyak 20 orang $(64,5 \%)$ dan jenis kelamin laki-laki sebanyak 11 orang (35,\%).Menurut peneliti, pada responden yang mengetahui dirinya positif mengidap HIV pasti akan mengalami permasalahan baik dalam dalam aspek biologis, psikologis, maupun sosial.(Sonya Arreola,2015)

\section{Usia}

Hasil dalam penelitian ini memperoleh bahwa usia pasien 25-35 tahun sebanyak 25 orang(80,6\%), usia 36-45 tahun sebanyak 5 orangmobilitas yang tinggi dan berinteraksi dengan banyak orang.

\section{Pendidikan}

Hasil penelitian ini memperoleh bahwa tingkat pendidikan terbanyak pada tingkat SMA 25 orang $(54,3 \%)$. Tingkat Pendidikan Menurut WHO (20014), 
menyebutkan bahwa pendidikan merupakan sarana seseorang dalam mendapatkan pengetahuan dan pengaruh perilaku

\section{Riwayat HIV}

Hasil penelitian ini memperoleh bahwa riwayat HIV yang tertinggi merupakan dari berganti ganti pasangan dengan jumlah 17 orang $(54,8)$.Perilaku Berisiko Penularan HIV Perilaku berisiko tinggi penularan HIVadalah orang yang mempunyai kemungkinan besar menularkan HIV pada orang lain karena perilakunya.( Ibidun,2015)

\section{StatusPe rnikahan}

Hasil penelitian ini memperoleh bahwa pasien HIV yang belum menikah sebanyak 29 orang $(93,6 \%)$ dan sudah menikah sebanyak 2 orang $(6,4 \%)$. Salah satunya di Afrika Selatan dilaporkan populasinya $66 \%$ hanya memiliki satu pasangan dan $79 \%$ tidak melakukan hubungan seksual sampai umur 17 tahun, namun $40 \%$ perempuan muda disana terinfeksi HIV meski mereka setia pada satu pasangan.

\section{HASIL PENELITIAN}

Distribusi Frekuensi Karateristik Resiliensi Penderita Hiv Di Puskesmas Kabupaten Karo

\begin{tabular}{lcc}
\hline DATA DEMOGRAFI & \multicolumn{2}{c}{ KETERANGAN } \\
\cline { 2 - 3 } RESPONDEN & $\mathbf{f}$ & $\%$ \\
$\quad$ Usia & \multicolumn{2}{c}{} \\
25-35Tahun & 5 & 80,6 \\
36-45Tahun & 1 & 36,1 \\
46 Tahun & & \\
Jenis Kelamin & & \\
$\quad$ Perempuan & 20 & 64,5 \\
$\quad$ Laki-laki & 11 & 35,5 \\
Pendidikan & & \\
SD & 0 & 0 \\
SMP & 0 & 0 \\
SMA & 24 & 77,4 \\
$\quad$ PT & 7 & 22,6 \\
\hline
\end{tabular}

\begin{tabular}{lrc}
\hline Agama & 18 & 58,1 \\
Islam & 4 & 12,9 \\
Katolik & 9 & 29,0 \\
KristenProtes an & & \\
$\quad$ Lamanya terkena HIV & 27 & 87,0 \\
$\quad$ Akut & 4 & 13,0 \\
$\quad$ Kronis & & \\
$\quad$ Status Pernikahan & 2 & 6,4 \\
$\quad$ Menikah & 29 & 93,6 \\
$\quad$ BelumMenikah & & \\
Juml ah Anak & 29 & 93, \\
$\quad 0$ & 1 & 6 \\
$\quad 1$ & 1 & 3,2 \\
2 & 0 & 3,2 \\
$\quad>2$ &
\end{tabular}

Ri wayat HIV

$\begin{array}{lccc}\begin{array}{l}\text { Ganti-ganti } \\ \text { Pasangan }\end{array} & & 14 & 45,2 \\ \text { Jarumsuntik } & & & \\ \text { Transfusidarah } & 17 & & 54, \\ & & 0 & 8\end{array}$

Pekerjaan

Petani

Pedagang Supir

IRT

$11 \quad 35,5$

Wiraswasta $\quad 18 \quad 58,0$

PNS $31 \quad 100$

Total

Hasil dalam penelitian ini riwayat pekerjaan pasien HIV adalah wiraswasta sebanyak 18 orang $(58,0 \%)$, supir 11 orang sebanyak $(35,5)$ dan ibu rumah tangga (IRT) sebanyak 2 orang $(6,5 \%)$. Berdasarkan jenis kelamin perempuan sebanyak 20 orang $(64,5 \%)$ dan jenis kelamin laki-laki sebanyak 11 orang (35,\%).Dari usia pasien didapati 25-35 tahun sebanyak 25 orang $(80,6 \%)$, usia $36-45$ tahun sebanyak 5 orang $(16,1 \%)$ danusia $\geq 46$ tahun sebanyak 1 orang $(3,3 \%)$. Dan tingkat pendidikan terbanyak pada tingkat SMA 25 orang $(54,3 \%)$. 


\section{PEMBAHASAN}

Hasil penelitian menunjukkan bahwa distribusi resiliensi penderita HIV di puskesmas Kabupaten Karo . Pada penelitian ini menunjukkan bahwa distribusi resiliensi penderita HIV di wilayah puskesmas kabupatan Karo, resiliensi yang sedang sebanyak 24 orang $(77,4)$ dan resiliensi yang tinggi sebanyak 3 orang $(9,7 \%)$. Penderita HIV yang mempunyai resiliensi yang tinggi ini salah satnya dipengaruhi oleh pendidikan, dukungan keluarga serta kekuatan yang terdapat dari dalam dirinya sendiri. Riwayat HIV yang lebih banyak terkena dari berganti ganti pasangan dan berjenis kelamin perempuan ini disebabkan oleh ekonomi yang rendah.

\section{SARAN}

\section{Bagi penderita HIV}

Disarankan bagi penderita HIV agar lebih mengenal penyakit yang dideritanya dan memahami cara penularan serta pencegahannya.

\section{DAFTAR PUSTAKA}

Djoerban, Z., \& Irawan, H. (2012). Quality of life people living with HIV/AIDS: outpatient in Kramat 128 Hospital Jakarta. Acta Med Indones, 44(4), 310316.

Dageid, Govender, Gordon.(2012). Masculinity and HIV disclosure among heterosexual South African men: implications for HIV/AIDS intervention

De castro Castrighini C, Reis RK, et all (2013) Epidemiological Profile of HIV/Tuberculosis Coinfection in the state of sao paulo,Brazil.J Antivir ntiretrovir $\quad 5: \quad 119-122$.
Doi:10.4172/jaa.1000074

Ibidun Fakoya, Débora Álvarez-delArco, et all (2015)A systematic review of postmigration acquisition of HIV among migrants from countries with generalised HIV epidemics living in Europe: mplications for effectively. BMC PublicHealth. 2015; 15:561.

Published online 2015 Jun 19. doi: 10.1186/s12889-015-1852-9

Sonya Arreola Glenn-Milo Santos.et all.Sexual Stigma, Criminalization, investment, and Acsess to HIV Services Among Men Who Have Sex with Men Worldwide.February 2015, Volume 19, Issue 2,pp 227-234

\section{World Health Organization.(2014). Globalsummary of the AIDS epidemic2013.,(http://www.who.int/hiv/ data/ep i_core_dec2014.png?ua=1, diaksespada 21 Maret 2017).}

